\title{
Spectrum of Morphologic Changes of Lymph Nodes in HIV Infection
}

\author{
DD Paiva/ ${ }^{+}$, JC Morais*, J Pilotto**, V Veloso***, F Duarte*, HL Lenzi****
}

Serviço de Anatomia Patológica, Departamento de Patologia e Laboratórios, Faculdade de Medicina, Universidade do Estado do Rio de Janeiro, Rua Prof. Manuel de Abreu 48, 20550-170 Rio de Janeiro, RJ, Brasil *Serviço de Anatomia Patológica, Departamento de Patologia **Serviço de Doenças Infecciosas e Parasitárias, Hospital Universitário Clementino Fraga Filho, Faculdade de Medicina, Universidade Federal do Rio de Janeiro,

Av. Brig. Trompowski s/no $-21949-900$ Rio de Janeiro, RJ, Brasil ***Hospital Carlos Chagas

****Departamento de Patologia, Instituto Oswaldo Cruz, Av. Brasil 4365, 21045-900

Rio de Janeiro, RJ, Brasil

Cervical lymph nodes biopsies from 31 HIV positive patients (with or without AIDS) were studied by histologic methods and immunohistochemistry (StreptABC staining of paraffin sections) to identify cellular and extracellular matrix components. The results were the following: (1) the biopsies were included in the stages of follicular hyperplasia without fragmentation FH-FF (4 cases); follicular hyperplasia with follicular fragmentation FH+FF (16 cases); follicular involution FI (6 cases) and diffuse pattern DP (5 cases); (2) the most important alteration was the germinal centers disruption due to follicle lysis, which began in the light zone; (3) there was coincidence between intrafollicular hemorrhages and segmental hyaline mycroangiopathy; (4) during the progression of the disease occurred: (a) an increase in the number of mast cells, CD68+ and Mac $387^{+}$macrophages; $(b)$ a diffuse augment of collagen III, elastic fibers, laminin, fibronectin and proteoglycans; (c) maintenance of Factor VIII related antigens in the vascular endothelial cells, with decrease in the expression of Ulex-Europeus I lectin. Follicular hyperplasia $(F H-F F$ or $F H+F F)$ was the most common histologic pattern recognized in the lymph nodes of patients without AIDS and follicular involution and difuse pattern were seen in those who had AIDS. The results indicate that the lymph node biopsies may provide important information about the evolutive stage of the disease and its prognosis.

Key words: lymph node - HIV - AIDS - extracellular matrix - mast cells - mycroangiopathy

One of the hallmarks of the infection by the human immunodeficiency virus (HIV) is the selective destruction of CD4 subset of T lymphocytes. Measures of $\mathrm{CD}^{+} \mathrm{T}$-lymphocytes are used to guide clinical and therapeutic management of HIVinfected persons. $\mathrm{CD}^{+} \mathrm{T}$ lymphocyte count had been included as a marker for HIV-related immunosuppression by the classification system for HIV infection from Centers for Disease Control (CDC 1992).

However, the most common histopathologic changes seen in lymph nodes from $\mathrm{HIV}^{+}$patients are mainly due to the $\mathrm{B}$ region reactivity, which is expressed by florid follicular hyperplasia, often progressing to follicular involution. Within the pattern of follicular hyperplasia, beyond several abnormalities of germinal centers (GCs), changes

This work was supported by CNPq, FIOCRUZ, UFRJ, UERJ.

${ }^{+}$Corresponding author. Fax: 55-21-590.3495

Received 7 December 1995

Accepted 10 January 1996 in paracortex and sinuses have also been described. Only later this was followed by depletion of $\mathrm{CD}^{+}{ }^{+}$ positive cells (Diebold et al. 1985, Stanley Frizzera 1986, Pallesen et al. 1987, Pantaleo \& Fauci 1995).

In the early stages of HIV infection, GC serve as an important reservoir of free virus in the interstitial spaces. This reservoir disappears as the GCs involute with advancing disease (Tenner-Rácz et al. 1986, Fox et al. 1991, Pantaleo et al. 1991).

The study of HIV-infected individuals at various stages of disease has indicated that, early in the course of HIV infection at a time when viral burden is low in peripheral blood, lymphoid organs serve as a major reservoir for HIV. Indeed, immune response to HIV as well as the spread of HIV infection occur predominantly within the microenvironment of the lymphoid tissues (Fox et al. 1991, Pantaleo et al. 1991, Pantaleo \& Fauci 1995).

Over the prolonged course of HIV disease, the complex follicular dendritc cells (FDCs) network within the germinal centers is gradually and progressively disrupted and ultimately destroyed (Biberfeld et al. 1985, 1987, Tenner-Rácz et al. 
1986, Baroni et al. 1988, Fox et al. 1991, Pantaleo et al. 1991, Baroni \& Uccini 1993, Frost \& Mclean 1994). Since the FDCs serve as the major antigenretaining cells forming a network for germinal centers B cells responses and memory, disruption of this microenvironment network is incompatible with an effective humoral immune response (Pantaleo \& Fauci 1995).

The histological alteration seen in HIV-related lymphadenopathy has been described with different terms by many authors (Table). To facilitate comparisons of results from various laboratories, a group of pathologists of the European Lymphoma Study Group has proposed a histological classification for the evaluation of HIV related lymphadenopathy (Öst et al. 1989).

Here we will present our experience on histopathology of lymph nodes from $\mathrm{HIV}^{+}$patients during different stages of the disease, focusing on architectural, cellular and extracellular matrix aspects.

\section{MATERIALS AND METHODS}

Patients - Thirty-one HIV positive patients, of whom 25 were males, varied from 20 to 59 years old. Eighteen of them were homosexual/bisexual and six also had used intravenous drugs. For three patients, the risk category was undetermined.

Eight patients were in stage III and 23 were in stage IV of CDC's classification.

Repeated lymph nodes biopsies were done on five patients, showing the following outcomes: one reproduced the same former lymph nodal pattern; other developed lymphoma; the third evolved from follicular hyperplasia to follicular involution; the others had tuberculosis, as an opportunistic infection.

Biopsy material - We examined 31 cervical lymph nodes biopsies from the patients. Case selection was based only on the availability of lymph nodes accessioned to the Department of Pathology at Federal University of Rio de Janeiro. Neoplastic or infected lymph nodes were excluded. All patients had the clinic diagnosis according to the surveillance case definition outlined by the CDC (1986).

Histologic methods - Each specimen was fixed in mercury-containing fixative B5 or neutral formalin and routinely processed into paraffin. Sections were stained with Hematoxilin and Eosin $(\mathrm{H}$ \&E); Lennert's Giemsa; Gomori's Silver Reticulin, Picrosirius plus polarization microscopy (Junqueira et al. 1979); PAS-Alcian Blue, pH 1.0 and 2.5 and Periodic Acid Methanamine Silver.

Immunohistochemical study - StreptaBC staining of paraffin sections was performed, after trypinization, with the following primary antibodies against cellular and extracellular matrix components: Mac387, CD68 (PG-N 1 ), CD35 (DRC1), $\mathrm{UCHL}_{1}$ (CD45 RO), CD20 (L26), S-100, p24, Factor VIII RA (DAKO) and Collagens III and IV, Laminin, Fibronectin (CHEMICON). The endothelial cells were also labeled with Ulex Europeus I-FITC (SIGMA).

TABLE

Classifications of lymph node morphology in HIV infection and AIDS

\begin{tabular}{|c|c|c|c|c|c|c|}
\hline $\begin{array}{l}\text { Fernandez } \\
\text { et al . } 1983\end{array}$ & $\begin{array}{l}\text { Marche } \\
\text { et al. } 1984\end{array}$ & $\begin{array}{l}\text { Biberfeld } \\
\text { et al. } 1985\end{array}$ & $\begin{array}{l}\text { Pallesen } \\
\text { et al. } 1987\end{array}$ & $\begin{array}{l}\text { Rácz } \\
\text { et al. } 1986\end{array}$ & $\begin{array}{l}\text { Chadburn } \\
\text { et al. } 1989\end{array}$ & $\begin{array}{l}\text { Öst } \\
\text { et al. } 1989\end{array}$ \\
\hline $\begin{array}{l}\text { Explosive } \\
\text { follicular } \\
\text { hyperplasia }\end{array}$ & $\begin{array}{l}\text { Type I } \\
\text { Lymphoid } \\
\text { follicular } \\
\text { hyperplasia }\end{array}$ & $\begin{array}{l}\text { Follicular } \\
\text { hyperplasia/ } \\
\text { follicular } \\
\text { fragmentation }\end{array}$ & Stage I & $\begin{array}{l}\text { Follicular } \\
\text { type }\end{array}$ & $\begin{array}{l}\text { Explosive } \\
\text { follicular } \\
\text { hyperplasia }\end{array}$ & $\begin{array}{c}\text { Follicular } \\
\text { hyperplasia } \\
\text { HF-FF } \\
\text { HF+FF }\end{array}$ \\
\hline $\begin{array}{l}\text { Mixed } \\
\text { pattern }\end{array}$ & $\begin{array}{l}\text { Type II } \\
\text { AIL-like }\end{array}$ & $\begin{array}{l}\text { Follicular } \\
\text { atrophy }\end{array}$ & Stage II & $\begin{array}{l}\text { Hypervascular } \\
\text { follicular } \\
\text { type }\end{array}$ & $\begin{array}{l}\text { Mixed } \\
\text { follicular } \\
\text { involution }\end{array}$ & $\begin{array}{l}\text { Follicular } \\
\text { involution }\end{array}$ \\
\hline \multirow[t]{2}{*}{$\begin{array}{l}\text { Follicular } \\
\text { involution }\end{array}$} & $\begin{array}{l}\text { Type III } \\
\text { Atrophy }\end{array}$ & $\begin{array}{l}\text { Follicular } \\
\text { depletion }\end{array}$ & Stage III & $\begin{array}{l}\text { Mixed } \\
\text { follicular } \\
\text { type }\end{array}$ & $\begin{array}{l}\text { Lymphocyte } \\
\text { depletion }\end{array}$ & $\begin{array}{l}\text { Diffuse } \\
\text { pattern }\end{array}$ \\
\hline & & & & $\begin{array}{l}\text { Follicular } \\
\text { involution }\end{array}$ & & $\begin{array}{l}\text { Special } \\
\text { features }\end{array}$ \\
\hline
\end{tabular}

AIL: angio-immunoblastic-lymphadenopathy-like, HF-FF: hyperplasia without severe fragmentation, $\mathrm{HF}+\mathrm{FF}$ : hyperplasia with severe fragmentation. 


\section{RESULTS}

Our results will be presented according to the European Lymphoma Study Group classification (Öst et al. 1989).

\section{HISTOPATHOLOGIC ASPECTS}

Follicular hyperplasia without follicular fragmentation $(F H-F F)$ - Four biopsies were included in this category and the lymph nodes presented the total area of hyperplasic follicles exceeding that of the interfollicular regions. The GCs were often irregular, occasionally they assumed dumbbell or other bizarre shapes and sometimes they were fused.

Germinal centers were usually in the third phase with zonal demarcation (Müller-Hermelink \& Lenert 1978). The dark zones were very active and rich in macrophages containing apoptotic detritus, which conferred a "starry sky" appearance (Fig. 1). Focal disruption of GCs by clusters of small mature lymphocytes was rarely observed.

The mantle zones were normal, reduced, noncontinuous or absent allowing the GCs to be in direct contact with the interfollicular zone. This zone presented a great population of $\mathrm{S}-100^{+}$ interdigitating dendritc cells (IDC) and an increase in postcapillary venules with high endothelia, which were strikingly positive for F-VIII related antigen and Ulex Europeus.

There were multiple focal aggregates of monocytoid cells characteristically located along fibrous septa, around the peripheral lymphocytic mantles of lymphoid follicles and in the sinuses. These cells were fairly large and uniform with clear cytoplasm, distinct cellular borders, and round, dark nuclei (Fig. 12). Plasma cells were prominent in the interfollicular zone, in medullary cords and were occasionally observed also in the GCs.

The sinuses were distended and filled with lymphocytes, monocytoid cells, macrophages and variable number of neutrophils and mast cells. Mast cells were also seen in the paracortical region. In a few cases, occasional multinucleated giant cells of Warthin-Finkeldey type were seen.

Follicular hyperplasia with follicular fragmentation $(F H+F F)$ - In this stage, which were observed in 16 biopsies, the lymph nodes also showed hyperplastic follicles, with marked variation in size and form. Characteristic disruption of GCs by clusters of small mature lymphocytes with or without associated extravasation of erythrocytes was often observed (Fig. 2). The intrafollicular capillary vessels, close to the follicular lysis, showed focal or segmented hyalinized $\left(\mathrm{PAS}^{+} / \mathrm{PAMS}^{+}\right)$thickening of the wall (Fig. 4).

The interfollicular zone maintained similar aspects described in FH-FF, showing also marked pro- liferation of arborizing postcapillary venules with high endothelia (Fig. 13). Macrophages, S-100 IDCs were frequently seen in the interfollicular zone and there was a pronounced increase in the number of plasma cells and mast cells.

The stages FH-FF and FH+FF were observed in lymph nodes from patients in CDC's stages III and IV, without opportunistic infection.

Follicular involution (FI) - Six biopsies were classified in this group. The capsule was thickened and there was predominance of the interfollicular areas. Most of the follicles were remarkable small and atrophic showing a typical hyaline vascular center, which was irregularly surrounded by large and nucleolated cells, resembling FDCs, and by a few layers of small lymphocytes (Fig. 5). The residual, predominantly small to medium-sized follicle center cells appeared non-proliferative and there was no starry sky pattern.

Follicular hyperplasia with several fragmentation and atrophic follicles could be frequently seen in the same lymph node. Arborizing HEVs in the paracortical areas and mast cells in the sinuses and interfollicular zone were increased (Fig. 10).

Diffuse pattern DP (follicular depletion) - The lymph nodes in five cases, presented a marked decrease in cellularity and a relative increase in vessels and fibrous tissue. The most prominent feature was the absence of distinct follicles and GCs (Figs 8, 14). A mixed population of lymphocytes, plasma cells, and mast cells was usually observed. Macrophages were prominent in the sinuses and parenchyma. The endothelial cells labeled with Fator VIII RA were weak or almost negative to Ulex Europeus-FITC.

Only AIDS patients presented the last two histopathological stages in the lymph nodes.

\section{IMMUNOHISTOCHEMISTRY}

In the group $\mathrm{FH}-\mathrm{FF}$ and $\mathrm{FH}+\mathrm{FF}$, the B cells (CD20) were the main population in the GCs, in the mantle and were spreadly located in the interfollicular zone. T cells (CD45 RO), as usual, predominated in the paracortical zone, but were also present in high number in the GCs and mantle zone. CD68 labeled macrophages in the sinuses, interfollicular/paracortical zones and inside the GCs (Fig. 9), while cells developed by MAC387 were observed in the subcapsular sinuses, inside the postcapillary venules and more rarely in the interfollicular parenchyma. FDCs were mainly marked by CD35 in the light zone of GCs in the third phase and in involutive GCs (Fig. 6). Interdigitating dendritc cells were $\mathrm{S}-100^{+}$in all stages of the disease.

The intrafollicular aggregates in the follicle lysis were composed by CD45 $\mathrm{RO}^{+} \mathrm{T}$ cells, inter- 


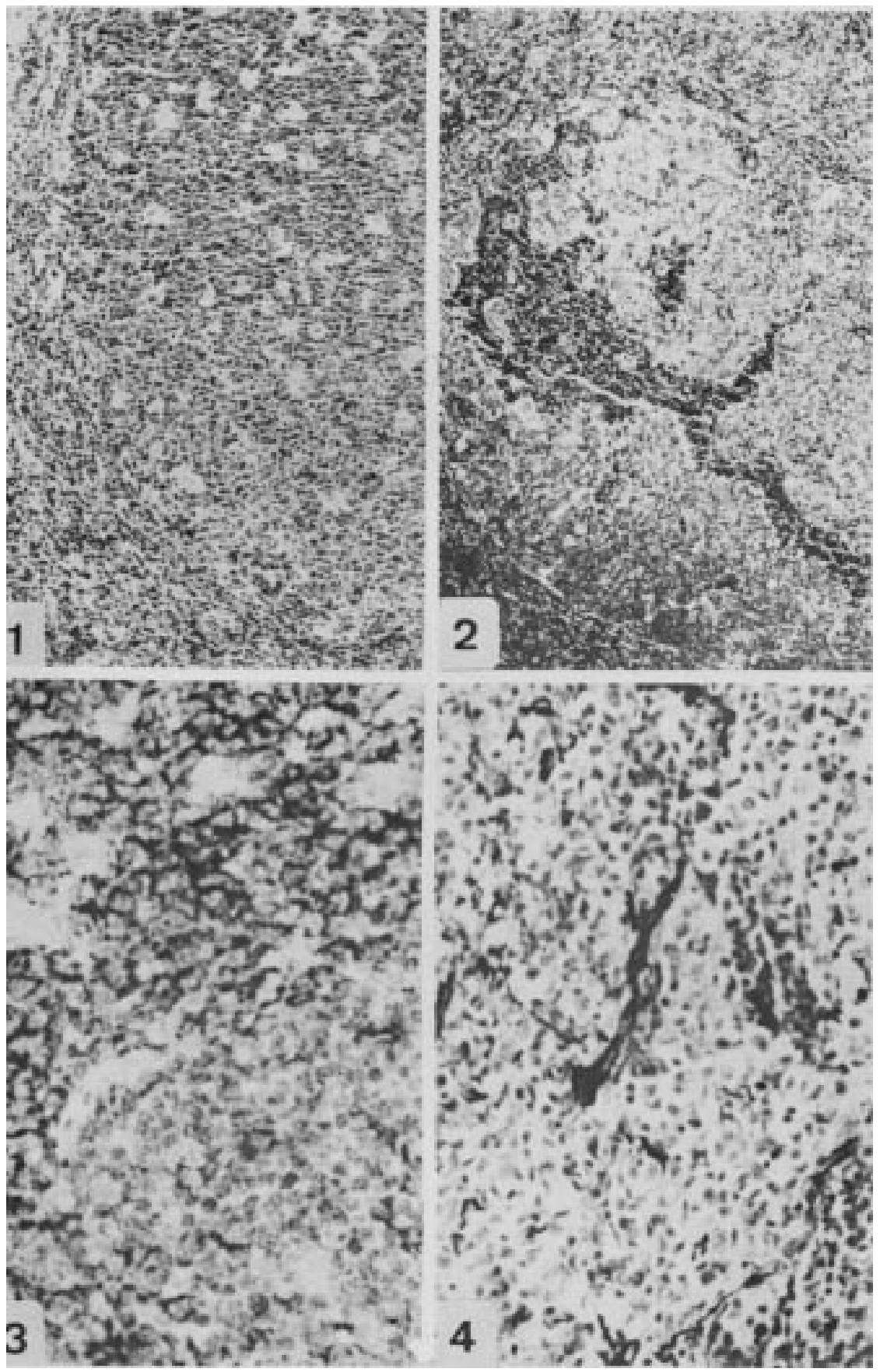

Fig. 1: follicular hyperplasia. A hyperplastic follicle, without mantle, with numerous centroblasts and many macrophages in the GC, acquiring the "starry sky" aspect (H\&E X 40). Fig. 2: follicle lysis. Disrupted GC invaded by aggregates of small lymphocytes and erythrocytes, which penetrate in the light zone (H\&E X 200). Fig. 3: CD20- small lymphocytes in follicle lysis bordered by CD20 ${ }^{+}$cells of GC (L26 courterstained with hematoxilin X 500). Fig. 4: follicular hyperplasia (HF+FF). Intrafollicular capillary vessel with hyaline thickening of the wall (PAMS X 310).

mixed with CD20+ B cells (Fig. 3). The lysis occurred in the light zone of the CCs causing patchy destrution of $\mathrm{CD} 35^{+}$FDCs.

In the DP group, due to loss of GCs and disarrangement of the normal architecture, the $\mathrm{T}$ and $\mathrm{B}$ lymphocytes and macrophages were mingled together, forming sometimes small and irregular aggregates, occuring an huge increase in the number of macrophages (Fig. 11). The S- $100^{+}$IDCs were significantly reduced, showing only small and 


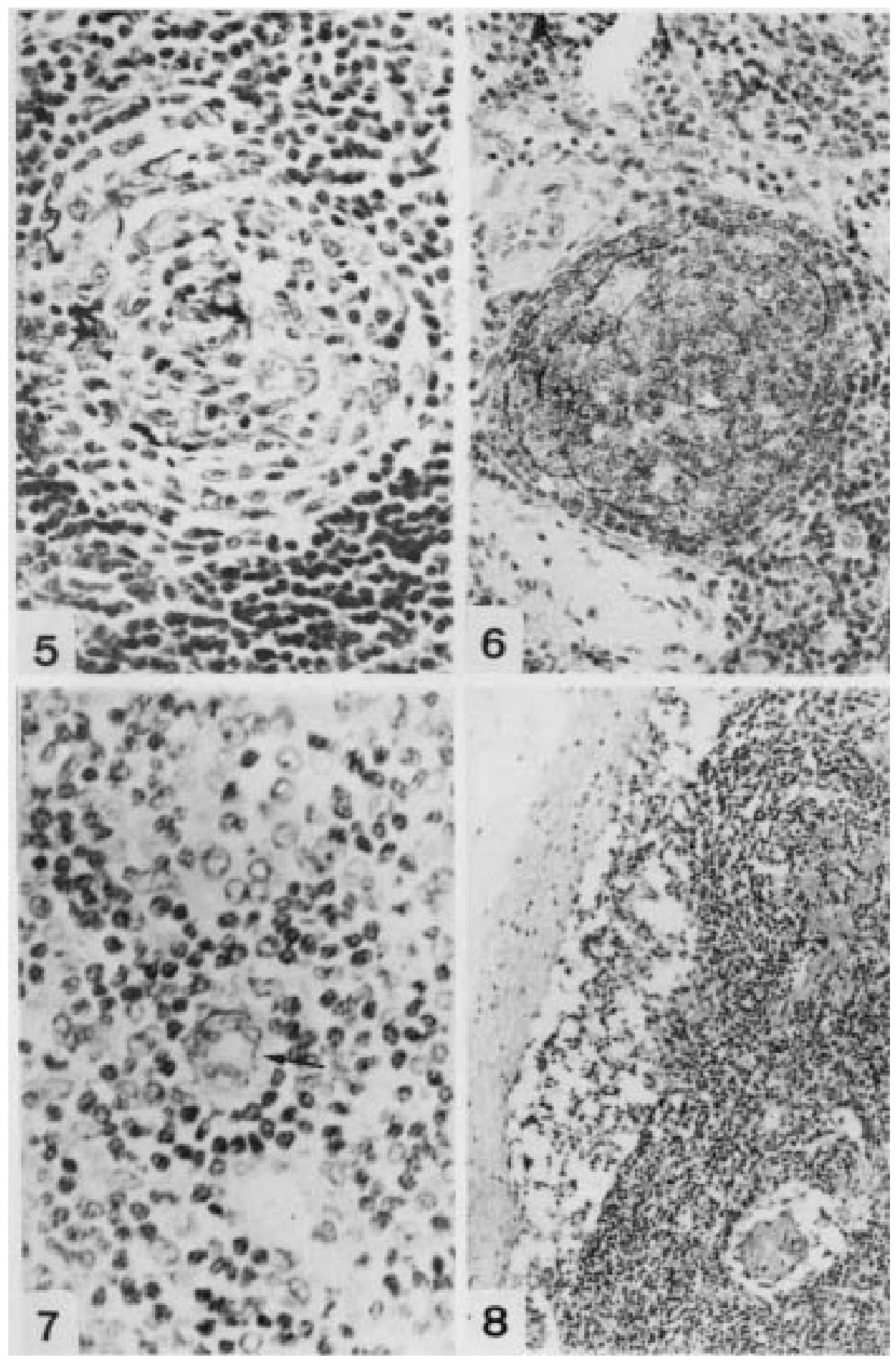

Fig. 5: follicular involution. Atrophic follicle presenting only FDCs and few small lymphocytes (PAMS X 500). Fig. 6: follicular involution. Mesh of FDC labeled by DCR-1 (CD35 courterstained with hematoxilin X 310). Fig. 7: high endothelium vessel in the paracortex stained with the monoclonal antibody anti-p24 (p24 courterstained with hematoxilin X 400). Fig. 8: follicular depletion. Lymph node with thickned capsule, absence of follicles and vascular proliferation (H\&E X 100).

sparse nests. The FI group presented intermediate changes between the FH and DP groups.

Sometimes, viral capsid protein p24 was sparcely detected in vascular walls, and in GC isolated cells (Fig. 7).

\section{EXTRACELLULAR MATRIX}

Reticular and $\mathrm{PAMS}^{+}$fibers in FH-FF and $\mathrm{FH}+\mathrm{FF}$ constituted a mesh in the paracortical area, with very well defined borders surrounding the follicles and with rare and isolated fibers inside the 

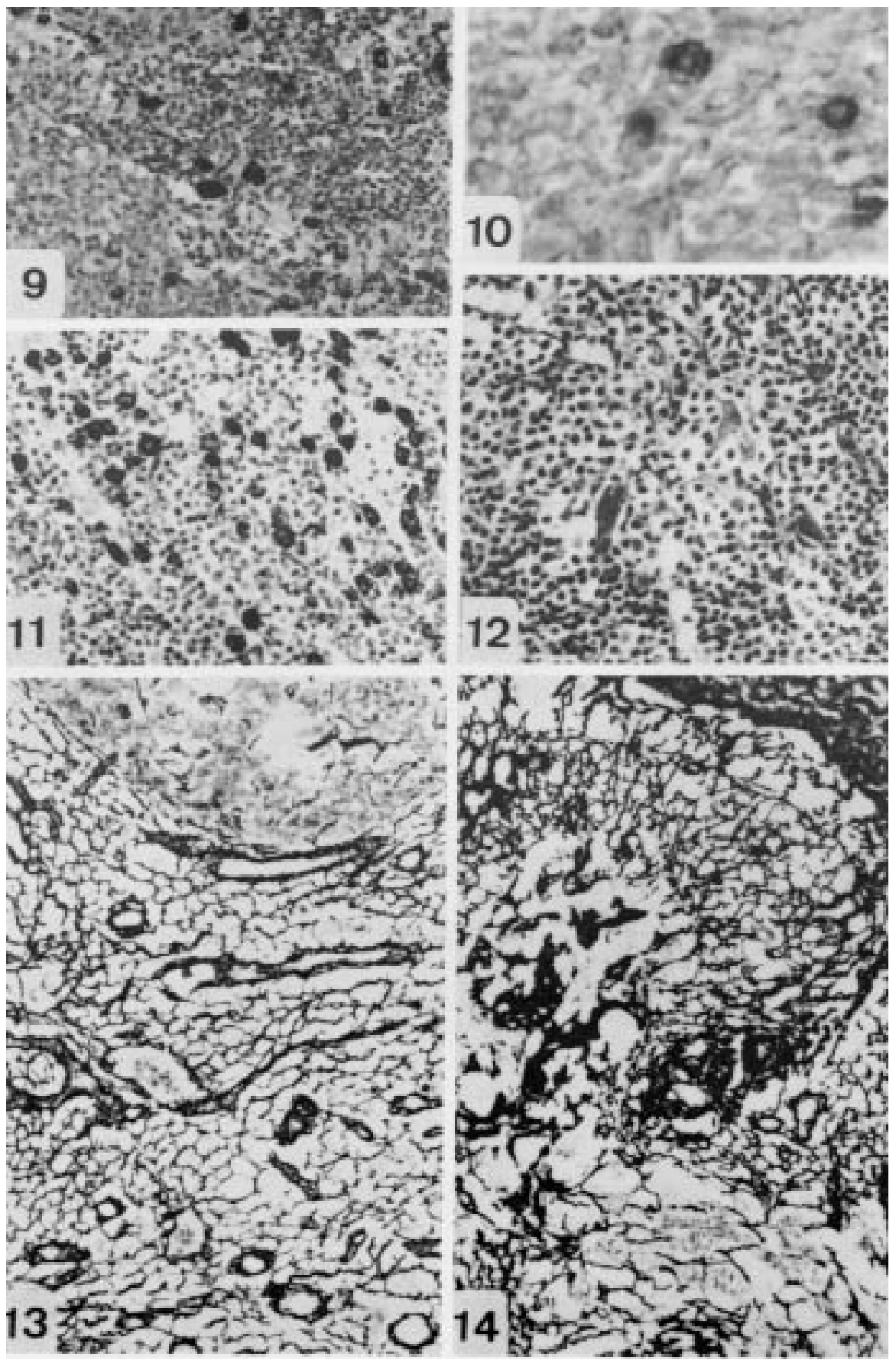

Fig. 9: follicle lysis. Macrophages inside fragmented area of GC labeled by CD68 (CD68 courterstained with hematoxilin X 200). Fig. 10: mast cells. Presence of mast cells in lymph node parenchyma of regressive phase (AB - PAS pH 1.0 X 640). Fig. 11: follicular depletion. Increase in the number of macrophages in lymph node parenchyma (Mac387 courterstained with hematoxilin X 310). Fig. 12: monocytoid cells. Aggregate of parasinusal cells with large and clear cytoplasm (H\&E X 400). Fig. 13: follicular hyperplasia (FH-FF). Reticular mesh in the paracortical zone, strengthened in the wall of proliferated vessels, showing clear demarcation in the border of GC (Gomori's reticulin X 200). Fig. 14: diffuse pattern. Reticulum staining showing collapse of the reticular fibers, expanded subcapsular sinus and transverse fibers connecting the capsule to the parenchyma (Gomori's reticulin X 200). 
GCs (Fig. 13). Otherwise, the elastic fibers developed after oxidation, predominated in the GCs, forming a fine intercellular network.

Collagen fibers were almost absent or scarce in the parenchyma of $\mathrm{T}$ and $\mathrm{B}$ zones, appearing predominantly in the capsule, trabeculae and vascular adventitia.

Carboxilated and sulfated proteoglycans revealed by $\mathrm{AB} \mathrm{pH} 2.5$ and 1.0, respectively, were expressed in the capsule, trabeculae and vascular endothelia. AB $2.5^{+}$proteoglycans were also detected in the cytoplasm of GC cells and in very delicate extracellular fibers.

In the more advanced stages, follicular involution (FI) and diffuse pattern DP (follicular depletion), the reticular and $\mathrm{PAMS}^{+}$fibers became thickener, sometimes collapsed, being exarcebated in the vascular walls, involutive GCs, and in subcortical sinuses (Fig. 14). Fibers of collagen type III and fibronectin appeared in the parenchyma, forming fibrillar meshes. Elastic fibers, laminin and $\mathrm{PAMS}^{+}$material clearly increased in the involutive or atrophyc GCs. Proteoglycans were more evident in the parenchyma, capsule and trabeculae.

\section{DISCUSSION}

The most important alteration in lymph nodes of HIV infected patients is the progressive destruction of the GCs which evolves to follicular depletion. Lymph nodes reaction patterns reflect the disorders of the immunity with severe progressive B and T CD4 ${ }^{+}$cells depletion (Diebold et al. 1985, Biberfeld et al. 1985, 1987, Tenner-Rácz et al. 1986, Stanley \& Frizzera 1986, Rácz et al. 1986, Pallesen et al. 1987, Baroni et al. 1988, Baroni \& Uccini 1993, Ioachin 1994).

Follicular dendritic cells are antigen trapping non-lymphoid cells that have crucial importance in pathogenesis of HIV infection. Ultrastructural, immunohistochemical, in situ hybridization and PCR studies revealed HIV particles and Ag retained in their network (Armstrong \& Horne 1984, Tenner-Rácz et al. 1985, Biberfeld et al. 1985, Le Tourneau et al. 1986, Baroni et al. 1988, Pantaleo et al. 1991). The HIV can destroy the FDCs, causing a gradual development of T CD4+ lymphopenia (Tenner-Rácz et al. 1986). The T CD4+ cells constantly traffic through the lymphoid follicles in contact with FDCs, becoming potentially infected via their CD4 molecules (Fox \& Cottler-Fox 1992).

Destruction of germinal centers, denominated "follicle lysis," consists of follicle fragmentation by clusters of small lymphocytes with or without associated extravasation of erythrocytes. It occurs mainly in the GC light zone, causing a disruption of the normal meshwork of FDCs, which predomi- nate in this area of the follicles. The formation of immune complexes (virus plus immunoglobulin or complement) would contribute to the attachment of HIV to the FDCs (Pantaleo et al. 1993). Our observations, together with the literature data (Wood et al. 1984, Biberfeldet al. 1985, Diebold et al. 1985, Pallesen et al. 1987) showed that the intrafollicular aggregates that penetrate in the GCs during follicle lysis were predominantly of $\mathrm{B}$ and T CD8 ${ }^{+}$cells, added to few intrafollicular $\mathrm{CD} 68^{+}$ macrophages.

There was coincidence between intrafollicular hemorrhages and focal or segmental diabetic-like mycroangiopathy inside the GCs. This finding suggests that the vascular lesions could be responsible for the microhemorrhages. The microangiopathy was probably due to vascular invasion by HIV, which was confirmed by focal detection of p24 in vessels.

Follicle lysis superficially resembles progressive transformation of germinal centers. However, in progressive transformation the influx of mantle zone cells seems to involve the entire circumference symmetrically, while in follicle lysis it is generally focal, patchy, or asymmetrical (Stanley \& Frizzera 1986), and occurs predominantly in the light zone as we mentioned in the results.

Mast cells increased in number from FH to FI stage onward and their exact contribution to this condition is unknown. However, they are implicated in tissue fibrosis and angiogenesis (Qu et al. 1995) and could contribute to fibrosis in regressive stages of HIV-related lymphadenopathy.

During the progression of the disease we detected changes in the extracellular matrix components, expressed by increase in collagen type III, elastic fibers, laminin, fibronectin and proteoglycans in the interstitium of the parenchyma, involutive GCs, capsula, trabeculae and vascular adventitia. Together with these qualitative changes, occurred also distortion of the reticular mesh, which became thicker and sometimes collapsed.

The fact that the elastic fibers mesh appear in the parenchyma, specially in the GCs, only after oxidation by oxone, implies that the fibers are of oxytalan type. It was impossible to conclude if the increase of these fibers in the involutive GCs was due to a collapse of the mesh or to an elastogenesis. We do not know yet what type of interactional effects occurs among lymphocytes and extracellular matrix components during the progression of the HIV infection in the lymph nodes.

The discrepancy, in the more advanced stages of the disease, between the Factor VIII RA (von Willebrand's factor) and Ulex Europeus 1 lectin 
expressions in vascular endothelial cells, suggests the occurrence of active vascular proliferation, with less differentiated endothelial cells, containing less alfa-L-fucose.

The CD68 and Mac387, which recognize lysosomal molecules and calcium binding proteins (calgranulins), respectively (Ellis 1993), showed that the macrophage populations in the lymph nodes are heterogeneous, and both increased during the infection. Only CD $68^{+}$macrophages were observed inside the GCs, while the Mac387 revealed also affluence of neutrophils to the compromised lymph nodes.

Our results confirmed the classical aspects described in specific literature. Follicular hyperplasia was the most common histologic pattern recognized in the lymph nodes of patients without AIDS and lymphoid depletion was seen for those who had developed AIDS. This indicates that the specification of histologic type in the diagnosis of HIV lymphadenopathy provides information about the stage of disease and indication about its prognosis (Ioachin 1994). Indeed, progressive disease was recognized in five patients with consecutive biopsies (Paiva 1992).

The mechanisms of follicle lysis and the participation of extracellular matrix components in the pathogenesis of the disease deserve further studies.

\section{ACKNOWLEDGMENTS}

To Jane Arnt Lenzi and Monica de Sousa Panasco for the manuscript review, and to Luzia Fátima Gonçalves Caputo and Adelaide Lopes Amorim for technical assistance.

\section{REFERENCES}

Armstrong JA, Horne R 1984. Follicular dendritic cells and virus-like particles in AIDS-related lymphadenopathy. Lancet ii: 370-372.

Baroni CD, Uccini S 1993. The lymphadenopathy of HIV infection. AJCP 99: 397-401.

Baroni CD, Pezzella F, Pezzella M, Macchi B, Vitolo D, Uccini S, Ruco L 1988. Expression of HIV in lymph node cells of LAS patients. Immunohistology, in situ hybridization and identification of target cells. Am J Pathol 133: 498-506.

Biberfeld P, Öst A, Porwit A, Sandstedt B, Pallesen G, Böttiger B, Morfeldt-Månsson L, Biberfeld G 1987. Histopathology and immunohistology of HTLV-III/ LAV related lymphadenopathy and AIDS. Acta Path Microbiol Immunol Scand 95: 47-65.

Biberfeld P, Porwit-Ksiazek A, Böttiger B, MorfeldtMånsson L, Biberfeld G 1985. Immunohistopathology of lymph nodes in HTLV-III infected homosexuals with persistent adenopathy or AIDS. Cancer Res 45: 4665s-4670s.

Chadburn A, Metroka C, Mouradian J 1989. Progressive lymph node hystology and its prognostic value in patients with acquired immunodeficiency syn- drome and AIDS-related complex. Hum Pathol 20. 579-587.

CDC - Centers for Disease Control and Prevention 1986. Classification system for human T-lymphotropic virus type III/lymphadenopathy-associated virus infections. MMWR 35: 334-339.

CDC - Centers for Disease Control and Prevention 1992. 1993 revised classification system for HIV infection and expanded surveillance case definition for AIDS among adolescents and adults. $M M W R$ 41: 119.

Diebold J, Marche CI, Audouin J, Aubert JP, Le Tourneau A, Bouton CI, Reynes M, Wizniak J, Capron F, Tricottet V 1985. Lymph node modification in patients with the acquired immunodeficiency syndrome (AIDS) or with AIDS related complex (ARC). A histological, immuno-histopathological and ultrastructural study of 45 cases. Path Res Pract 180: 590-611.

Ellis WE 1993. Lymphproliferative disorders, p. 109207. In AS-Y Leong, Applied Immunohistochemistry for the Surgical Pathologist. Edward Arnold, London.

Fernandez R, Mouradian J, Metroka C, Davis J 1983. The prognostic value of histopathology in persistent generalized lymphadenopathy in homosexual men. N Engl J Med 309: 185-186.

Fox CH, Cottler-Fox M 1992. The pathobiology of HIV infection. Immunol Today 13 : 353-356.

Fox CH, Tenner-Rácz K, Rácz P, Firpo A, Pizzo PA, Fauci AS 1991. Lymphoid germinal centers are reservoirs of human Immunodeficiency virus type 1 RNA. J Infect Dis 164: 1051-1057.

Frost SDW, McLean AR 1994. Germinal center destruction as a major pathway of HIV pathogenesis. J AIDS $7: 236-244$

Ioachim HL 1994. Human immunodeficiency virus lymphadenitis. p. 73-82. In Lymph Node Pathology. Lippincott, Philadelphia.

Junqueira LCU, Bignolas G, Brentani RR 1979. Picrosirius staining plus polarization microscopy a specific method for collagen detection in tissue sections. Histochem J 11: 447.

Le Tourneu A, Audouin J, Diebold J, Marche C, Tricottet V, Reynes M 1986. LAV-like viral particles in lymph node germinal centers in patients with the persistent lymphadenopathy syndrome and the acquired immunodeficiency syndrome-related complex. An ultrastructural study of 30 cases. Hum Pathol 17: 1047 1053.

Marche C, Kernbaum S, Saimot AG, Neguesse Y, Bouton C, Diebold J, Regnier B, Vittecoq D 1984. Histopathological study of lymph nodes in lymphadenopathy and acquired immune deficiency syndrome. Eur J Clin Microbiol 31: 75-76.

Müller-Hermelink HK, Lennert K 1978. The cytologic, histologic, and functional bases for a modern classification of lymphomas, p. 1-71. In K Lennert, $M a$ lignant lymphomas other than Hodgkin's disease. Springer-Verlag, Berlin.

Öst A, Baroni CD, Biberfeld P, Diebold J, Moragas A, Noël H, Pallesen G, Rácz P, Schipper M, Tenner- 
Rácz K, Van Den Tweel JG 1989. Lymphadenopathy in HIV infection histological classification and staging. APMIS (suppl) 8: 7-15.

Pallesen G, Gerstoft J, Mathiesen L 1987. Stages in LAV/ HTLV-III lymphadenitis. I.Histological and immunohistological classification. Scand J Immunol 25: 83-91.

Pantaleo G, Graziosi C, Butin L, Pizzo PA, Schnittman SM, Kotler DP, Fauci AS 1991. Lymphoid organs function as major reservoirs for human immunodeficiency virus. Proc Natl Acad Sci USA 88: 98389842.

Paiva DD 1992. Infecção pelo VIH e síndrome de imunodeficiência adquirida (SIDA): Estudo do gânglio linfático. MSc thesis - Universidade Federal do Rio de Janeiro - UFRJ, Rio de Janeiro, 116 pp.

Pantaleo G, Fauci AS 1995. New concepts in the immunopathogenesis of HIV infection. Annu Rev Immunol 13: 487-512.

Pantaleo G, Graziosi C, Demarest JF, Butini L, Montronit M, Fox CH, Orenstein JM, Kotler DP, Fauci AS 1993. HIV infection is active and progressive in lymphoid tissue during the clinically latent stage of disease. Nature 362: 355-358.

Qu Z, Liebler JM, Powers MR, Galey T, Ahmadi P, Huang X-N, Ansel JC, Butterfield JH, Planck SR,
Rosenbaum JT 1995. Mast cells are a major source of basic fibroblast growth factor in chronic inflammation and cutaneous hemangioma. Am J Pathol 147: 564-573.

Rácz P, Tenner-Rácz K, Kahl C, Feller AC, Kern P, Dietrich M 1986. Spectrum of morphologic changes of lymph nodes from patients with AIDS or AIDSrelated complexes. Prog Allergy 37: 82-181.

Stanley MW, Frizzera G 1986. Diagnostic specificity of histologic features in lymph node biopsy specimens from patients at risk for the acquired immunodeficiency syndrome. Hum Pathol 17: 1231-1239.

Tenner-Rácz K, Rácz P, Bofill M, Schulz-Meyer A, Dietrich M, Kern P, Weber J, Pinching AJ, VeroneseDimarzo F, Popovic M, Klatzmann D, Gluckman JC, Janossy G 1986. HTLV-III/LAV viral antigen in lymph nodes of homosexual men with persistent generalized lymphadenopathy and AIDS. Am $J$ Pathol 123: 9-15.

Tenner-Rácz K, Rácz P, Dietrich M, Kern P 1985. Altered follicular dendritic cell and virus-like particles in AIDS and AIDS-related lymphadenopathy. Lancet I: $105-106$.

Wood GS, Garcia CF, Dorfman RF, Warnke RA 1984. The immunohistology of follicle lysis in lymph node biopsies from homosexual men. Blood 66: 10921097. 
HIV Lymphadenopathy • DD Paiva et al. 